\title{
THE JQURNATE
}

OF

\section{MENTAL SCIENCE}

(THE BRITISH JOURNAL OF PSYCHIATRY)

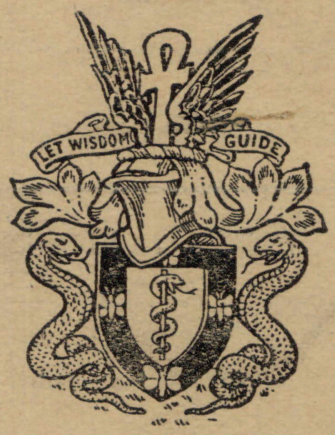

BY AUTHORITY OF

THE ROYAL MEDICO-PSYCHOLOGICAL ASSOCIATION

EDITOR-IN-CHIEF

G. W. T. H. FLEMING

CO-EDITORS

Alexander Walk and P. K. McCowan

AND WITH THE ASSISTANCE OF

E. D. Adrian

E. G. Holmes

F. C. Bartlett

C. J. McCarthy

S. M. Coleman

Alfred Meyer

C. J. C. Ear1

Lionel S. Penrose

Sir A. Fleming

F. L. Golla

A. A. W. Petrie

E. T. O. Slater

W. Stephenson

LONDON

J. \& A. CHURCHILL, LTD

Published Four times Yearly, Ten Shillings and Sixpence net 


\section{THE JOURNAL OF MENTAL SCIENCE}

Communications on general editorial matters, including MSS. for publication, books for review and other printed matter, and communications regarding the Epitome section, including journals to be abstracted, should be sent to the Editor-in-Chief, Barnwood House, Gloucester.

Communications and inquiries regarding sales should be addressed to the Publishers, Messrs. J. \& A. GHURCHILL, Ltd., 104, Gloucester Place, Portman Square, London, W.1; and those regarding Advertisements to Messrs. S. \& H. FRETWELL, Ltd., 92, Fleet Street, London, E.C.4. Phone: Central 5587/8.

\section{THE ROYAL MEDIGO-PSYGHOLOGIGAL ASSOGIATION.}

\section{PUBLICATIONS.}

From Messrs. Adlard \& Son, Ltd.,

Bartholomew Press, Dorking, Surrey.

Enquiry (History) Form, for use in Mental Hospitals. In three sizes. Prices and specimen forms on application.

Card of Practical Instruction. Prices on application.

From Messrs. J. \& A. Ghurahill, Ltd., I04 Gloucester Place, W. I "The Journal of Mental Science." Published four times a year. Price 10/6. Postage
extra.

From Messrs. Baillière, Tindall \& Cox, 8 Henrietta Street, W.G. 2

"Handbook for Mental Nurses." 8th edn. In preparation.

"Manual for Mental Deficiency Nurses." I931. Price 6/6 net.

"Occupational Therapy." Addendum to "Handbook." 1938. Price 6d.

From the Registrar, Southfield, Shipton Road, York.

"Syllabuses," for the Examinations for the Gertificates of Proficiency in Mental Nursing and in Nursing Mental Def=ctives. Price 2d. each. Postage Id. "Regulations and Rules for the Nursing Examinations." Revised, r938. Price 9d.
each. Postage Id.

"Examination Papers, r928-38." Price 9d. each. Postage rd.

"Regulations for the D.P.M. of the R.M.P.A." Price 3 d. Postage Id.

From the Secretary, i I Chandos Street, W. I.

The Charter and Bye-Laws of the Association. Price 2/-. Postage $I \frac{1}{2} \mathrm{~d}$. 


\section{triple-vitamin}

\section{routine}

\section{in psychological illness}

Loss of appetite, gastro-intestinal upsets and skin affections are commonly met with as symptoms or complications of mental disorder. Such conditions may well reflect a deficiency of one or more of the principal water soluble vitamins- $\mathrm{B}_{1}, \mathrm{C}$ and nicotinic acid-and these are the three vitamins combined in Nicorbin Tablets. Three Nicorbin Tablets daily provide adequate nutritional amounts of aneurine, ascorbic acid and nicotinic acid. The vitamin $B_{1}$ stimulates the patient's appetite; vitamin $\mathrm{C}$ affords protection against sub-scorbutic lesions to which the aged patient and others on restricted diet are particularly prone; nicotinic acid is effective in many cases of sore tongue, diarrhoea and dermatitis and is, of course, the specific pellagra-preventing factor. Nicorbin therefore has welldefined applications in the mixed nutritional deficiency states so often associated with psychological illness.

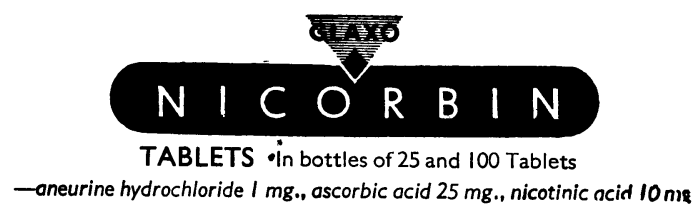

GLAXO LABORATORIES LTD., GREENFORD, MIDDLESEX. BYRon 3434 


\section{ELECTRIC CONVULSION THERAPY \\ for treatment of Melancholia, Mental \& Psychiatric Disorders (EDISWAN MODEL)}

\section{MEDICAL OBSERVATIONS:}

Many thousands of cases have been successfully treated by this method, including sufferers from I NVOLUTIONA L MELANCHOLIA, CLIMACTERIC DEPRESSION,RECENTMANIA, ACUTE PSYCHOSES AND OTHER PSYCHIATRIC DISORDERS.

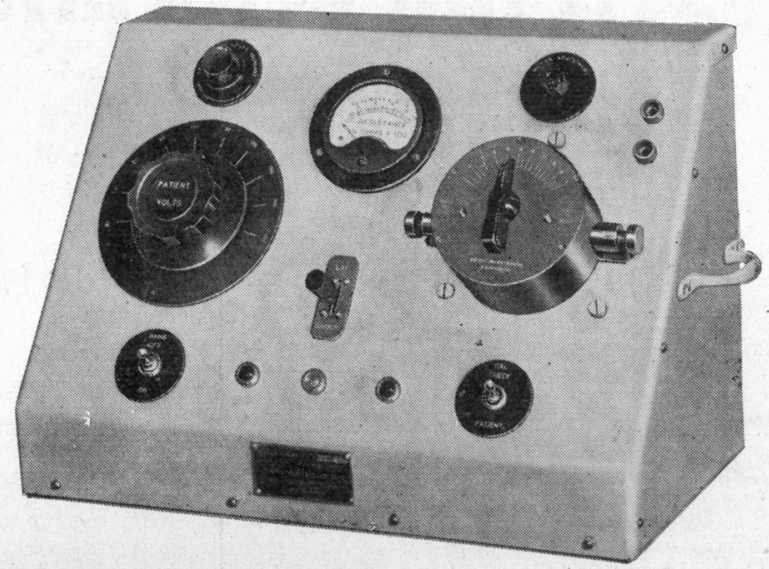

An apparatus constructed to specification of Mr. GREY WALTER. The ideal method for inducing epileptiform seizures. Administration is simple, speedy and effective. Complete amnesia of patient. Apparatus is portable and is in use in more than 250 Hospitals.

Please write for brochure describing technique together with clinical data and bibliography.

\section{COX-CAVENDISH ELECTRICAL CO., LTD.}

Phone :]

45-47 Marylebone High Street, London, W. I [WELbeck 2886-7

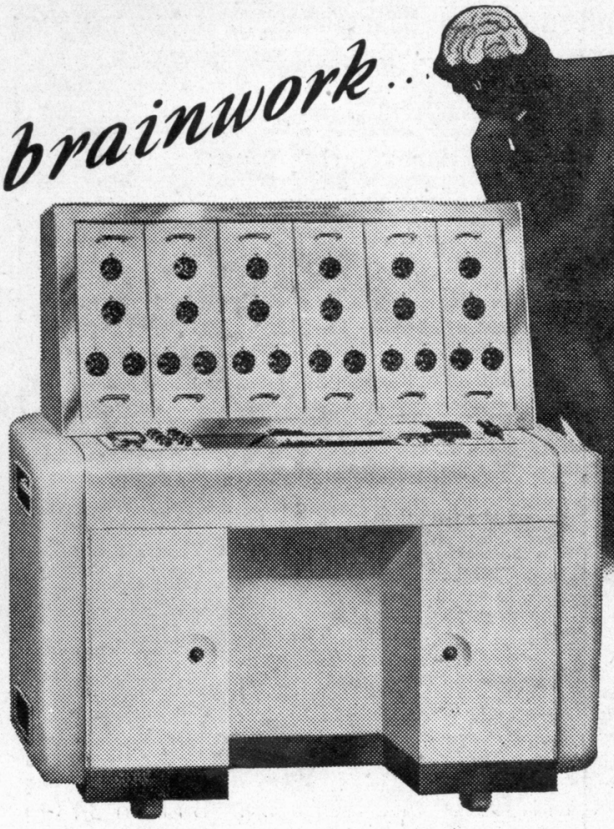

Particulars are available on request.

The new Marconi 6-Channel Electro - Encephalograph is designed for brainwork of the most analytical kind. Electrically as efficient as its prototype, the two extra channels permit the exercise of every refinement in E.E.G. technique. The convenience of the operator has been studied to such effect that a new conception of functional design has emerged.

THE

\section{Marconi 6Channel} ELECTROENGEPHALOGRAPH 


\section{ST. ANDREW'S HOSPITAL \\ FOR NERVOUS AND MENTAL DISORDERS NORTHAMPTON}

President: The Most Hon. The MARQUeSS OF EXETER, K.G., C.M.G., A.D.C.

Medical Superintendent: THOMAS TENNENT, M.D., F.R.C.P., D.P.H., D.P.M.

This Registered Hospital is situated in 130 acres of park and pleasure grounds. Voluntary patients who are suffering from incipient mental disorders or who wish to prevent recurrent attacks of mental trouble, temporary patients, and certified patients of both sexes are received for treatment. Careful clinical, bio-chemical, bacteriological, and pathological examinations. Private rooms with special nurses, male or female, in the Hospital or in one of the numerous villas in the grounds of the various branches can be provided.

\section{WANTAGE HOUSE}

This is a Reception Hospital in detached grounds with a separate entrance, to which patients can be admitted. It is equipped with all the apparatus for the complete investigation and treatment of Mental and Nervous Disorders by the most modern methods; insulin treatment is available for suitable Mental and Nervous Disorders by the most modern methods; insulin treatment is available for suitable
cases. It contains special departments for hydrotherapy by various methods, including Turkish and Russian baths, the prolonged immersion bath, Vichy Douche, Scotch Douche, Electrical baths, Plombières treatment, etc. There is an Operating. Theatre, a Dental Surgery, an X-Ray Room, an Ultra.Violet Apparatus, and a Department for Diathermy and High-Frequeney treatment. It also contains Laboratories for biochemical, bacteriological, and pathological research. Psychotherapeutic treatment is employed when indicated.

\section{MOULTON PARK}

Two miles from the Main Hospital there are several branch establishments and villas gituated in a park and farm of 650 acres. Milk, meat, fruit and vegetables are supplied to the Hospital from the farm, gardens, and orchards of Moulton Park. Occupational therapy is a feature of this branch, and patients are given every facility for occupying themselves in farming, gardening and fruit-growing.

\section{BRYN-Y-NEUADD HALL}

The seaside house of St. Andrew's Hospital is beautifully situated in a Park of 330 acres at Llanfair. fechan, amidst the finest scenery in North Wales. On the North-West side of the Estate a mile of sea-coast forms the boundary. Patients may visit this branch for a short seaside change or for longer periods. The Hospital has its own private bathing house on the seashore. There is trout-fishing in the park.

At all the branches of the Hospital there are cricket grounds, football and hockey grounds, lawn tennis courts (grass and hard courts), croquet grounds, golf courses, and bowling greens. Ladies and gentlemen have their own gardens, and facilities are provided for handicrafts, such as carpentry, etc.

For terms and further particulars apply to the Medical Superintendent (Telephone No. 2356 and 2357 Northampton), who can be seen in London by appointment.

\section{HEIGHAM HALL, NORWICH}

PRIVATE MENTAL HOME

for Nervous and Mental illness. All forms of treatment available. Fees from 5 gns. per week upwards, according to requirements. Vacancies occasionally exist at reduced fees on the recommendation of the patient's own physician.

Apply to Dr. J. A. SMALL. TELEPHONE: NORWICH 20080.

\section{LAVERSTOCK HOUSE SALISBURY}

\section{PRIVATE MENTAL HOME FOR LADIES AND GENTLEMEN}

Completely up to date. Lovely house and grounds ( 18 acres). Certified and uncertified cases taken. Facilities for going to the seaside.

\section{ESTABLISHED OVER 200 YEARS}

Apply to the Med. Supt. for illustrated brochure.

Tel.: SALISBURY 2612. 


\section{In depressive states... .}

the central nervous stimulant of choice

$\mathbf{T}^{\mathrm{N}}$ N DEPRESSIVE conditions 'Dexedrine' may be relied on to effect a remarkable improvement in mood and outlook, and to aid the patient in regaining a normal grip on life and living. The striking preponderance of its central nervous effect over its weak peripheral activity makes
'Dexedrine' virtually a single-action drug. Patients are ordinarily spared the disturbing consciousness of 'drug stimulation', and thus 'Dexedrine' is especially suitable for the highly-strung, the emotionally unstable, convalescents, men and women undergoing the climacteric, and the aged.
Available for prescription in packs of 24 tablets. Samples and literature on request.

\section{'DEXEDRINE' ${ }_{\text {TABLETS }}$}

物

(5 mg. dextro-amphetamine sulphate)

MENLEY \& JAMES, LTD., 123 Coldharbour Lane, London, S.E.5 For Smith Kline \& French International Co., owner of the Trade Mark.

\section{The PLEXACON Universal Electroplexy Unit}

\section{-the Psychiatrist's instrument of choice}

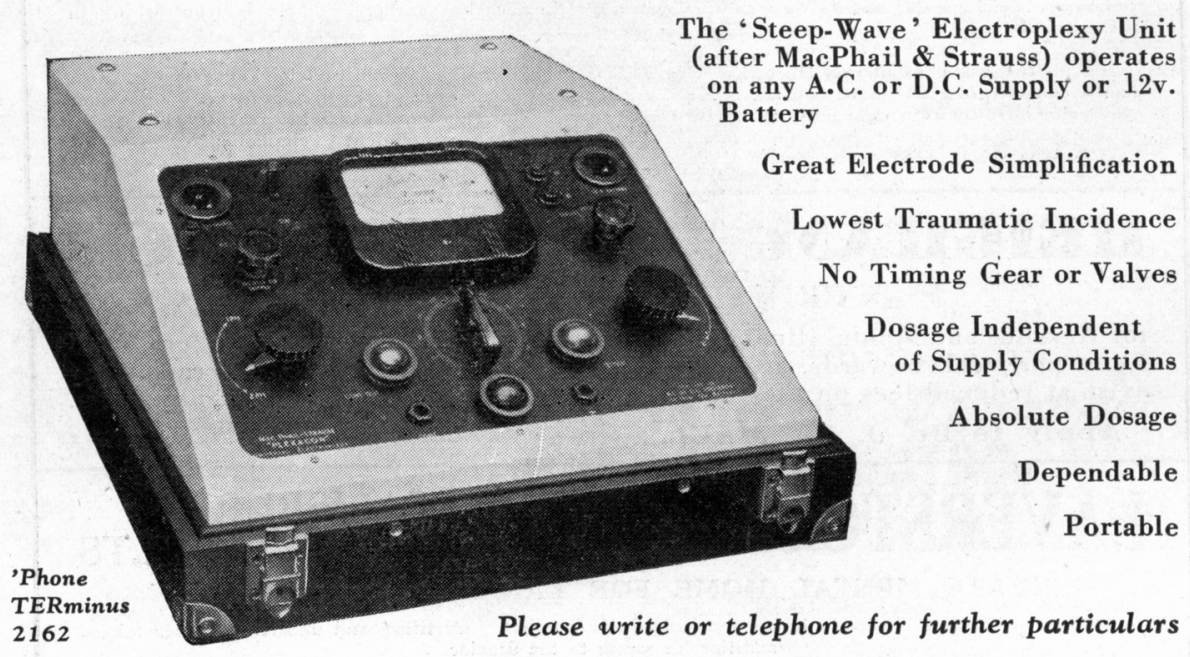

THERATRONICS Ltd. (Dept. B. 1), 6 Argyle Walk, London, W.C. 1 


\section{BARNWOOD HOUSE}

\section{GLOUCESTER}

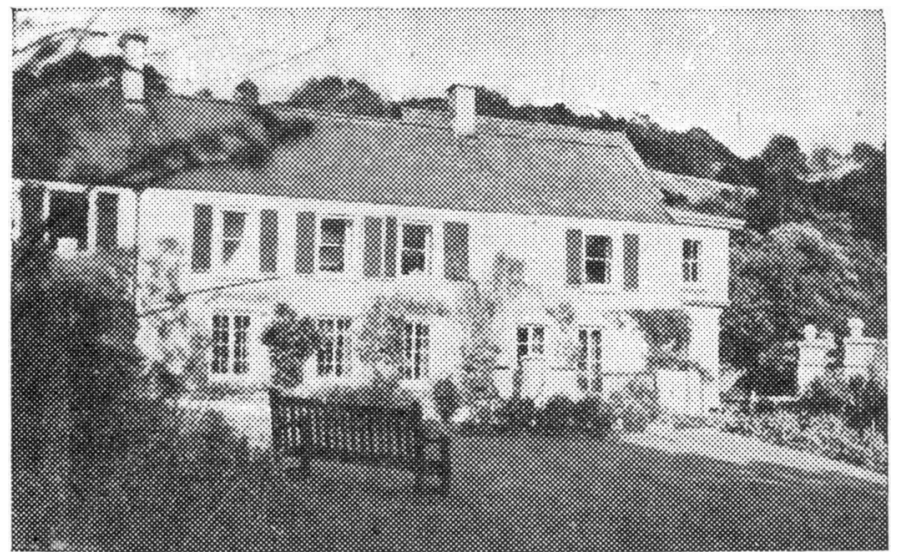

GRIGKLEY GOURT-ONE OF THE SEPARATE VILLAS

A REGISTERED HOSPITAL for the CARE and TREATMENT of LADIES and GENTLEMEN suffering from NERVOUS and MENTAL DISORDERS. Within two miles of the Western and London Midland Regional Railway Stations at Gloucester, the Hospital is easily accessible by rail from London and all parts of the United Kingdom. It is beautifully situated at the foot of the Cotswold Hills, and stands in its own grounds of over 300 acres. Voluntary Patients of both sexes are also received for treatment. Special accommodation is also provided at three villa residences, all of which stand in their own grounds and are entirely separate from the main Hospital. All the most modern methods of treatment including electric shock and prefrontal leucotomy are used.

$$
\text { For Terms, etc., apply to }
$$

G. W. T. H. FLEMING, M.R.C.S., L.R.C.P., D.P.M., Physician Superintendent, who may be seen in London by appointment

Telephone: No. 66207 Gloucester 


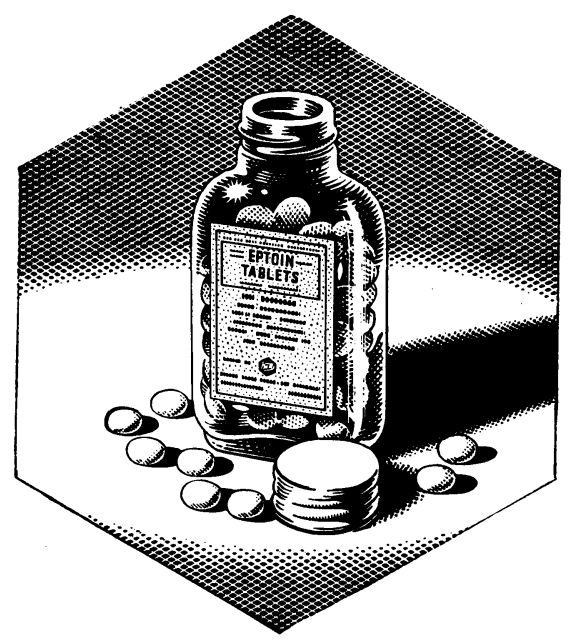

\section{Greatest}

\section{anti-convulsant action,}

\section{least hypnotic effect}

EPTOIN is a preparation of soluble phenytoin supplied as sugar-coated tablets containing o.I G. for the treatment of epilepsy. It possesses powerful anti-convulsant action and low hypnotic effect. Clinical results indicate that Eptoin greatly reduces the number of seizures in cases which have proved refractory to other forms of therapy.

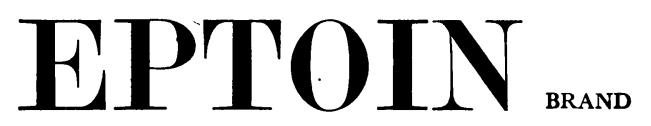

SOLUBLE PHENYTOIN for Epilepsy

Literature and further information gladls sent on request to Medical Dept.

BOOTS PURE DRUG CO. LTD., NOTTINGHAM, ENGLAND 


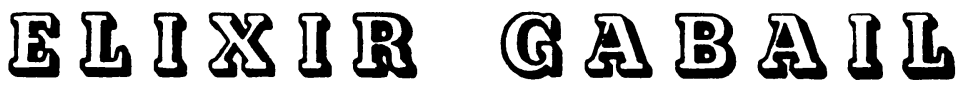 I BROMO-VALERIANATEI}

The Ideal Sedative in all Nervous Affections

Elixir Gabail combines the sedative action of Bromide and Chloral Hydrate with the nervine and anti-spasmodic deodorised Valerianate. Pharmaceutically it is as pleasant and palatable as it is efficacious from the therapeutic standpoint, the disagreeable odour and flavour of the Valerian having been completely removed without in any way impairing its therapeutic value.

In Hysteria and Psychasthenia it relieves nervous excitement and produces a calm state of mind that is conducive to rapid recovery. It is also of value in states of temporary emotional excitement, in Hypochondriasis and Melancholia.

Dosage : One tablespoonful in water twice or thrice daily. As a hypnotic : two tablespoonfuls in water at bedtime.

Supplied in bottles of 187 c.c.. 16 ozs., and in bulk for Hospital use.

Literature and Samples on request.

\section{The ANGLO-FRENCH DRUG Co. Ltd.}

11-12, Guilford Street, London, W.C. 1 


\section{THE INTERNATIONAL JOURNAL Of SEXOLOGY incorporating MARRIAGE HYGIENE}

Managing Editor: A. P. PILlAY Editor for Great Britain: CYRIL BIBBY with the following Editorial Board:

CLIFFORD ALLEN

E. ELKAN

\begin{abstract}
AMBROSE APPELBE
KENNETH WALKER
\end{abstract}

F. A. E. CREW HELENA WRIGHT

Vol 3, No 1

\section{Principal contents :}

August 1949

HELENA WRIGHT. A Contribution to the Orgasm Problem in Women. DONALD BUCKLE. The Treatment of Sex Offenders.

C. E. EDDY. The Effects of Radiation on the Gonads.

HELEN HEARDMAN. Natural Childbirth.

A. APPELBE \& C. MURDOCH. Recent Decisions on Consummation. EWALD BOHM. Sex Education: its Principles and Limitations.

Abstracts-Notes-Reviews-Correspondence-etc.

Summaries of all original papers in French and German.

Quarterly, 6s. Annual subscription, 22s.

Descriptive leaflet, with the principal contents of the previous issues, will be gladly sent on request

THE BIOTECHNIC PRESS LTD., BCM/BIOTECHNIC, LONDON, W.C.1 


\section{ADLARD \& SON}

LIMITED

\section{BARTHOLOMEW PRESS}

DORKING - SURREY

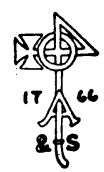

PRINTERS OF THIS :: :: JOURNAL

\section{ESTIMATES SUBMITTED PROMPTLY}

FOUNDED IN 1766, the Firm has continued uninterruptedly, and is able to undertake ALL CLASSES OF PRINTING.

The Staff is Specially Trained in the production of all printed matter connected with Private Hospitals and Homes, Medical, Scientific and other Institutions.

Efficient ...

Portable ...

Size, $7 \frac{1}{2} \times 4 \times 4$ inches Weight, $6 \frac{3}{4}$ lbs.

Simple in use...

Designed primarily for Intensified ECT, it is equally suitable for all forms of ECT.

In use at many leading mental hospitals.

Please write for. full details to:

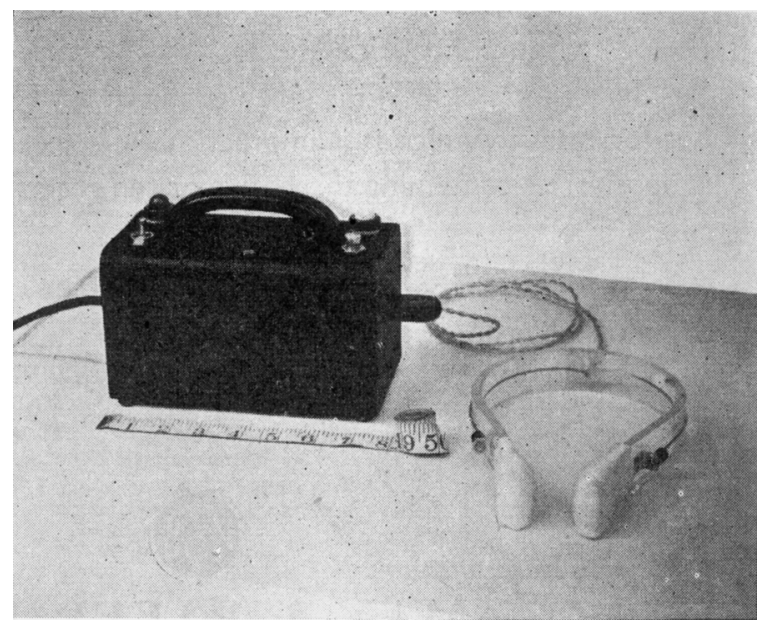

REEVES ELECTRICAL AND RADIO CO. LTD. REELEK WORKS, BALDOCK, HERTS., ENGLAND Telegrams: "Reelek" Baldock Telephone: Baldock 154 


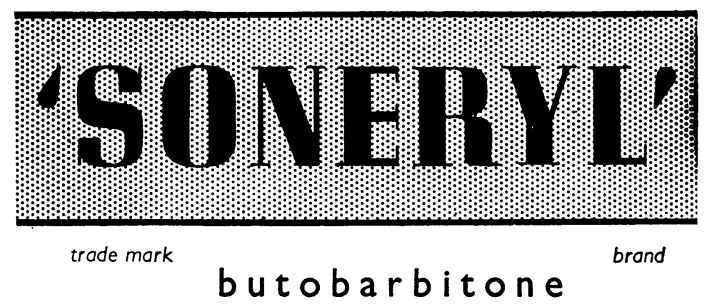

short sedation to

$$
\begin{aligned}
& \text { prollonged } \\
& \text { n a r c o s i s }
\end{aligned}
$$

One of the advantages of 'Soneryl' is the ease with which, by graduating the dose, the degree of action may be varied from the mildly sedative to the deeply hypnotic.

This is of particular interest in psychiatric practice for it enables the one drug to be used as a hypnotic in all the mental states from simple anxiety to intractable psychosis. It may be given for long periods with minimal side effects.

Generally 'Soneryl' is given orally in tablets (grains $\mid \frac{1}{2}$ in each), but for cases in which it is impracticable to give the drug by mouth, suppositories containing three, five or ten grains of 'Soneryl' are available.

Tablets in containers of

$12,25,100$, and 500

Suppositories of gr. $3, \mathrm{gr} .5$, and gr. 10, in boxes of 5

OUR MEDICAL INFORMATION DIVISION WILL BE PLEASED TO SEND A COPY OF THE MEDICAL BOOKI.ET 'SONERYL' ON REQUEST

manufactured by

MAY \& BAKER LTD

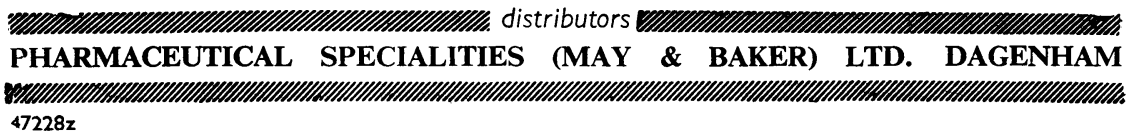

[Facing first matter 